\title{
Evaluation of Provenances for Drupe, Seed and Germination Traits in Teak (Tectona grandis L. F.)
}

\author{
Ravindra Kumar Dhaka* and Suman Kumar Jha
}

Department of Forest Biology and Tree Improvement, College of Forestry, ACHF, Navsari Agricultural University, Navsari, Gujarat - 396 450, India

*Corresponding author

\section{A B S T R A C T}

The most valuable timber of the world i.e. teak (king of timber) was widely used due to its durability, physical and aesthetic property. It has a high demand in international market and distributed throughout India and Southeast Asia. In addition, there are huge gap between demand and supply of industrial timber in India. This can be fulfilled by the teak plantation with agroforestry systems. Therefore, five provenances i.e. Mandvi, Vyara, Vansda, Chikhali and Dharampur from Gujarat natural teak forests had been selected for

\section{Keywords}

King of timber, Drupe, Provenance,

Heritability, Genetic gain, Associations.

Article Info

Accepted:

15 September 2017 Available Online:

10 November 2017 the study to select the better seed source for plantation industry. Our result showed significant differences $(\mathrm{p} \leq 0.01)$ in all the studied characteristics. Drupe were lengthiest $(11.14 \mathrm{~mm})$, broadest $(12.64 \mathrm{~mm})$ and heaviest $(58.38 \mathrm{~g})$ in Mandvi provenance followed by Dharampur provenance, whereas smallest $(9.69 \mathrm{~mm})$, narrowest $(10.48 \mathrm{~mm})$ and lightest (35.49 g) in Vansda provenance. Similarlly seed length, seed width, 100 seed weight, filling percent, drupe and seed germination were highest in Mandvi provenance while lowest in Vansda provenance. Overall, Mandvi and Dharampur provenance were performed better than all others. It was interesting to see that seed germination was increased 3-4 folds as compare to drupe germination. This showed that there is a physical dormancy due to hard or stony hard seed coat in teak fruit for poor drupe germination. Heritability was revealed that selection can be made for seed germination $\left(h^{2}=0.98\right)$ as further genetic improvement of teak while genetic gain coupled with 100 drupe weight (34.55). Strong inter-character correlation was found among all the traits and drupe as well as seed traits were influenced on the drupe and seed germination. So, seed germination among teak provenances was newly added parameter to confirm the presence of physical dormancy which was a major limiting factor for poor drupe or fruit germination for deployment of superior genetic materials.

\section{Introduction}

Tectona grandis Linn. f. (family: Lamiaceae) is the king of timber due to its durability, physical and aesthetic property. Teak is the most demanded tropical hardwood for a specific market of "luxury" applications including furniture, shipbuilding and decorative building components (Pandey and
Brown, 2000), which is resistant to termite and insect attacks (Tewari, 1992). It is a deciduous diploid tree species with $2 \mathrm{n}=36$ chromosomes (Hedegart and Eigaard, 1965) up to $40 \mathrm{~m}$ tall. It is native to Southeast Asia and India; distributed in the states of Kerala, Tamil Nadu, Karnataka, Andhra Pradesh, 
Telengana, Maharashtra, Gujarat, Chhattisgarh, Madhya Pradesh, Rajasthan, Uttar Pradesh, Manipur, Orissa etc. (Tewari, 1992). Although the Indian state Gujarat have natural teak forest in Dangs, Valsad, Navsari, Tapi, Vadodara, Panchmahal, Dahod, Sabarkantha and Junagarh districts (GFS, 2012).

There is a huge gap between demand and supply of industrial timber i.e. 20 million $\mathrm{m}^{3}$ in 1997 and is projected to be touching around 110 million $\mathrm{m}^{3}$ by 2090 in India (NRCAF, 2007). This demand can be fulfilled by teak plantation with agroforestry systems, but still, there are two major problems i.e. low seed yield and extremely low germination rates for the teak plantation industry as well as researchers (Kaosa-ard, 1981).

Drupe and seed related traits such as fruit weight, seed size, seed mass and germination are central components of plant life histories (Thompson, 1987), which highly influence on reproduction and seedling establishment (Grime et al., 1988).

Thus, seed size, seed dormancy and seed dispersal has long been conceived significant impact on reproductive biology of plants and creating fitness interaction with changing environment (Venable and Brown, 1988). Genetic variation among fruit, seed and germination traits has been documented for economically useful species such as Tectona grandis (Jayasankar et al., 1999; Sivakumar et al., 2002), Gmelina arborea (Lauridsen, 2004; Hodge and Dvorak, 2004), Cordia africana (Loha et al., 2006; Loha et al., 2009), Faidherbia albida (lbrahim et al., 1997), Khaya senegalensis (Ky-Dembele, 2014), Millettia ferruinea (Loha et al., 2008) etc. in the tropical environment. Therefore, the present study has been taken with the specific objectives: (1) to determine variation of drupe, seed and germination traits among teak provenances (2) to select better traits on the basis of heritability and genetic gain, and (3) to look inter-character association between traits.

\section{Materials and Methods}

The present research was conducted to evaluate the five provenances for drupe, seed and germination traits of teak in Gujarat state. Fruits/ drupes were collected during April to July, 2015 from five provenances i.e. Mandvi, Vyara, Vansda, Chikhali and Dharampur (Fig. 1; Table 1). The Latitude, longitude and altitude was recorded with the help of GPS (Table 1).

400 fruits/drupes of 10 trees from each provenance in four replications (100 fruits/ replications) were measured for analysis of the drupe and seed attributes. Drupe and seed traits viz. length $(\mathrm{mm})$, width $(\mathrm{mm})$ and mass (g) were recorded for all the provenances and average was computed.

Then drupe was broken by using Falcon Pruning Secateur to observe number of seed filling drupe (with one or more seed/kernel in a drupe). Drupe and seed were sown separately in the nursery beds with sand: soil: FYM (2:1:1) and germination was recorded up to 6 months. All standard nursery practices followed such watering, weeding etc. time to time.

These data were subjected to statistical analysis using MS excel 2007 and ANOVA was constructed for studied parameters. Genetic components like heritability (Zobel and Talbert, 1984; Falconer and Mackay, 1996), genetic advance and genetic gain (Johnson et al., 1955) were measured. Simple correlation coefficients were worked out to know the association among characters as per the method is given by Panse and Sukhatme (1978). 


\section{Results and Discussion}

\section{Phenotypic variation for drupe, seed and germination attributes among provenances}

There were significant differences $(p \leq 0.01)$ in all the studied traits among five provenances of $T$. grandis (Table 2).

Drupe was lengthiest in Mandvi provenance $(11.14 \pm 0.23 \mathrm{~mm})$ followed by Dharampur provenance $(10.93 \pm 0.28 \mathrm{~mm})$ and smallest in Vansda provenance $(09.02 \pm 0.11 \mathrm{~mm})$ of teak (Table 3). The drupe was broadest in the Mandvi provenance $(12.64 \pm 0.38 \mathrm{~mm})$ and narrowest in Vansda provenance $(10.48 \pm 0.13$ $\mathrm{mm})$. The 100 drupe weight was heaviest in the Mandvi provenance $(58.38 \pm 4.59 \mathrm{~g})$ whereas, the lightest drupe mass was observed in Vansda provenance $(35.49 \pm 0.76$ g). Highest drupe filling percentage was recorded in Mandvi provenance $(77.00 \pm 1.08$ $\%$ ), while lowest in Vansda provenance $(68.75 \pm 1.25 \%)$. Similarly, longest, thickest and heaviest seed of teak was observed in Mandvi provenance followed by Dharampur provenance, whereas shortest in Vansda provenance (Table 3). Drupe and seed germination percentage was highest in Mandvi provenance $(18.00 \pm 1.68,64.25 \pm 1.55$ $\%$ ) whereas lowest in Vansda provenance $(10.25 \pm 0.85,44.75 \pm 1.80 \%)$. Overall, Mandvi and Dharampur provenance were performed better than all others. It was interesting to see that seed germination was increased 3-4 folds as compare to drupe germination (Table 3). This showed that there is a physical dormancy due to hard or stony hard seed coat in teak fruit. This physical dormancy was also reported by Slator et al., (2013) for the cause of poor germination in teak. Jayasankar et al., (1999) studied variation in teak drupe characters of different seed sources in seven provenances. Variation in different physical drupe traits such as drupe diameter, drupe weight, shell weight, mesocarp weight among
30 seed sources from three countries was observed by Sivakumar et al., (2002). Sojan and Indira (2010) also analyzed variability of seed related characters in teak from western ghat region among 10 provenances and found that the mean value of drupe diameter length, drupe diameter width and 100 drupe weights were $12.3 \mathrm{~mm}, 13.6 \mathrm{~mm}$ and $53.01 \mathrm{~g}$, respectively. There are several other tropical tree species where such type seed related variation found to be useful for tree improvement such as Gmelina arborea (Lauridsen, 2004; Hodge and Dvorak, 2004); Faidherbia albida (lbrahim et al., 1997); Millettia ferruinea (Loha et al., 2008); Cordia africana (Loha et al., 2006; Loha et al., 2009); Khaya senegalensis (Ky-Dembele, 2014). Thus, this variation should be captured and used for tree improvement programme of teak in the Gujarat state.

Genetic components, heritability, genetic advances and genetic gain in teak

Highest heritability value was found for seed germination (0.98) trait followed by seed width (0.89) while minimum for drupe germination (0.63) trait. This is clearly indicated that seed germination trait was strong genetically controlled as compared to drupe germination trait. Genetic advance (16.16) and genetic gain (34.55) was highest for 100 drupe weight whereas minimum for seed width (0.80) and drupe filling percentage (8.63), respectively. Therefore, the genetic gain as percentage of mean give better selection criteria such as 100 drupe weight in teak for choose better provenance (Table 4). Rawat and Bakshi (2011) estimate the genetic component for cone, seed and germination traits in Pinus wallichiana. They reported highest heritability for 1000 seed mass in $P$. wallichiana and highest genetic gain for cone weight. Similar genetic variation for fruit, seed and germination traits has been accounted such as Millettia ferruinea (Loha et 
al., 2008); Cordia africana (Loha et al., 2006; Loha et al., 2009). Thus, drupe mass is the best trait where selection can be made for further genetic improvement and better option for maintaining genetic diversity from selection.

Table.1 Geo-climatic variables of different provenances of Tectona grandis

\begin{tabular}{lccccc}
\hline Provenance & $\begin{array}{c}\text { Latitude } \\
(\mathbf{N})\end{array}$ & $\begin{array}{c}\text { Longitude } \\
(\mathbf{E})\end{array}$ & $\begin{array}{c}\text { Altitude } \\
(\mathbf{m})\end{array}$ & $\begin{array}{c}\text { Annual Rainfall } \\
(\mathbf{m m})\end{array}$ & $\begin{array}{c}\text { Annual Temperature } \\
\left({ }^{\circ} \mathbf{C}\right)\end{array}$ \\
\hline Mandvi & $21^{\circ} 14^{\prime} 51.0^{\prime \prime}$ & $73^{\circ} 18^{\prime} 54.8^{\prime \prime}$ & 110 & 1539 & 27.4 \\
Vyara & $20^{\circ} 59^{\prime} 26.4^{\prime \prime}$ & $73^{\circ} 28^{\prime} 12.2^{\prime \prime}$ & 120 & 1705 & 27.2 \\
Vansda & $20^{\circ} 45^{\prime} 41.3^{\prime \prime}$ & $73^{\circ} 28^{\prime} 32.1^{\prime \prime}$ & 155 & 2154 & 26.9 \\
Chikhali & $20^{\circ} 37^{\prime} 56.2^{\prime \prime}$ & $73^{\circ} 12^{\prime} 38.4^{\prime \prime}$ & 135 & 1999 & 27.1 \\
Dharampur & $20^{\circ} 30^{\prime} 52.1^{\prime \prime}$ & $73^{\circ} 15^{\prime} 58.6^{\prime \prime}$ & 130 & 2303 & 26.8 \\
\hline
\end{tabular}

Table.2 Analysis of variance for drupe, seed and germination traits in $T$. grandis

\begin{tabular}{lrrr}
\hline \multirow{2}{*}{ Traits } & \multicolumn{3}{c}{ Provenance $(\mathbf{d f}=\mathbf{4})$} \\
\cline { 2 - 4 } & Mean Square & F Value & P > F \\
\hline Drupe Length & 3.079 & 16.515 & $<0.01$ \\
Drupe Width & 2.974 & 9.293 & $<0.01$ \\
100 Drupe Weight & 342.369 & 14.09 & $<0.01$ \\
Drupe Filling & 45.175 & 22.873 & $<0.01$ \\
Seed Length & 1.685 & 16.077 & $<0.01$ \\
Seed Width & 0.712 & 43.142 & $<0.01$ \\
100 Seed Weight & 1.465 & 27.127 & $<0.01$ \\
Drupe Germination & 36.425 & 7.709 & $<0.01$ \\
Seed Germination & 244 & 243.568 & $<0.01$ \\
\hline
\end{tabular}

Table.3 Mean variation for drupe, seed and germination traits among provenances of $T$. grandis

\begin{tabular}{lccccccccc}
\hline Provenance & $\begin{array}{c}\text { Drupe } \\
\text { Length } \\
(\mathbf{m m})\end{array}$ & $\begin{array}{c}\text { Drupe } \\
\text { Width } \\
(\mathbf{m m})\end{array}$ & $\begin{array}{c}\mathbf{1 0 0} \text { Drupe } \\
\text { Weight } \\
(\mathbf{g})\end{array}$ & $\begin{array}{c}\text { Drupe } \\
\text { Filling } \\
(\mathbf{\%})\end{array}$ & $\begin{array}{c}\text { Seed } \\
\text { Length } \\
(\mathbf{m m})\end{array}$ & $\begin{array}{c}\text { Seed } \\
\text { Width } \\
(\mathbf{m m})\end{array}$ & $\begin{array}{c}\text { 100 Seed } \\
\text { Weight } \\
(\mathbf{g})\end{array}$ & $\begin{array}{c}\text { Drupe } \\
\text { Germination } \\
(\boldsymbol{\%})\end{array}$ & $\begin{array}{c}\text { Seed } \\
\text { Germination } \\
(\boldsymbol{\%})\end{array}$ \\
\hline Mandvi & $11.14 \pm 0.23$ & $12.64 \pm 0.38$ & $58.38 \pm 4.59$ & $77.00 \pm 1.08$ & $6.03 \pm 0.25$ & $4.01 \pm 0.15$ & $6.00 \pm 0.16$ & $18.00 \pm 1.68$ & $64.25 \pm 1.55$ \\
Vyara & $09.69 \pm 0.20$ & $11.45 \pm 0.25$ & $39.87 \pm 1.75$ & $70.75 \pm 1.11$ & $4.72 \pm 0.12$ & $3.27 \pm 0.13$ & $4.71 \pm 0.11$ & $11.50 \pm 0.65$ & $48.25 \pm 1.93$ \\
Vansda & $09.02 \pm 0.11$ & $10.48 \pm 0.13$ & $35.49 \pm 0.76$ & $68.75 \pm 1.25$ & $4.50 \pm 0.14$ & $2.91 \pm 0.15$ & $4.54 \pm 0.14$ & $10.25 \pm 0.85$ & $44.75 \pm 1.80$ \\
Chikhali & $10.20 \pm 0.14$ & $12.13 \pm 0.23$ & $47.69 \pm 1.97$ & $71.25 \pm 1.38$ & $5.03 \pm 0.07$ & $3.46 \pm 0.14$ & $4.98 \pm 0.11$ & $13.25 \pm 0.85$ & $54.25 \pm 1.80$ \\
Dharampur & $10.93 \pm 0.28$ & $12.33 \pm 0.35$ & $52.41 \pm 1.82$ & $75.00 \pm 1.58$ & $5.70 \pm 0.16$ & $3.72 \pm 0.16$ & $5.54 \pm 0.15$ & $14.75 \pm 0.63$ & $58.50 \pm 1.44$ \\
\hline Mean & $\mathbf{1 0 . 2 0}$ & $\mathbf{1 1 . 8 0}$ & $\mathbf{4 6 . 7 7}$ & $\mathbf{7 2 . 5 5}$ & $\mathbf{5 . 1 9}$ & $\mathbf{3 . 4 7}$ & $\mathbf{5 . 1 5}$ & $\mathbf{1 3 . 5 5}$ & $\mathbf{5 4 . 0 0}$ \\
\hline SE(m) \pm & 0.22 & 0.28 & 2.47 & 0.70 & 0.16 & 0.06 & 0.12 & 1.09 & 0.50 \\
C.D. & 0.67 & 0.88 & 7.68 & 2.19 & 0.50 & 0.20 & 0.36 & 3.39 & 1.56 \\
C.V. & 4.24 & 4.79 & 10.54 & 1.94 & 6.24 & 3.70 & 4.51 & 16.04 & 1.85 \\
\hline
\end{tabular}


Table.4 Variance and genetic component for drupe, seed and germination traits in T. grandis

\begin{tabular}{lrrrrr}
\hline Traits & $\begin{array}{c}\text { Phenotypic } \\
\text { Variance }\end{array}$ & $\begin{array}{c}\text { Genotypic } \\
\text { Variance }\end{array}$ & Heritability & $\begin{array}{c}\text { Genetic advance } \\
(\mathbf{K}=\mathbf{2 . 0 6})\end{array}$ & $\begin{array}{c}\text { Genetic gain } \\
(\boldsymbol{\%})\end{array}$ \\
\hline Drupe Length & 0.91 & 0.72 & 0.79 & 1.55 & 15.20 \\
Drupe Width & 0.98 & 0.66 & 0.67 & 1.37 & 11.61 \\
100 Drupe Weight & 103.82 & 79.52 & 0.77 & 16.16 & 34.55 \\
Drupe Filling & 12.78 & 10.80 & 0.85 & 6.26 & 8.63 \\
Seed Length & 0.50 & 0.40 & 0.80 & 1.17 & 22.54 \\
Seed Width & 0.19 & 0.17 & 0.89 & 0.80 & 23.05 \\
100 Seed Weight & 0.41 & 0.35 & 0.85 & 1.12 & 21.75 \\
Drupe Germination & 12.65 & 7.93 & 0.63 & 4.62 & 34.10 \\
Seed Germination & 61.75 & 60.75 & 0.98 & 15.86 & 29.37 \\
\hline
\end{tabular}

Table.5 Inter-character correlation matrix among drupe, seed and germination traits of $T$. grandis

\begin{tabular}{|c|c|c|c|c|c|c|c|c|c|}
\hline Traits & $\begin{array}{c}\text { Drupe } \\
\text { Length }\end{array}$ & $\begin{array}{l}\text { Drupe } \\
\text { Width } \\
\end{array}$ & $\begin{array}{c}100 \text { Drupe } \\
\text { Weight }\end{array}$ & $\begin{array}{l}\text { Drupe } \\
\text { Filling } \\
\end{array}$ & $\begin{array}{c}\text { Seed } \\
\text { Length }\end{array}$ & $\begin{array}{c}\text { Seed } \\
\text { Width } \\
\end{array}$ & $\begin{array}{c}100 \text { Seed } \\
\text { Weight }\end{array}$ & $\begin{array}{c}\text { Drupe } \\
\text { Germination }\end{array}$ & $\begin{array}{c}\text { Seed } \\
\text { Germination }\end{array}$ \\
\hline Drupe Length & 1 & & & & & & & & \\
\hline Drupe Width & $0.96^{* *}$ & 1 & & & & & & & \\
\hline 100 Drupe Weight & $0.98 * *$ & $0.95 *$ & 1 & & & & & & \\
\hline Drupe Filling & $0.96^{* *}$ & $0.88 *$ & $0.96 * *$ & 1 & & & & & \\
\hline Seed Length & $0.97 * *$ & $0.89 *$ & $0.97 * *$ & $0.99 * *$ & 1 & & & & \\
\hline Seed Width & $0.98 * *$ & $0.96 * *$ & $0.98 * *$ & $0.97 * *$ & $0.97 * *$ & 1 & & & \\
\hline 100 Seed Weight & $0.95 *$ & $0.87^{\mathrm{NS}}$ & $0.97 * *$ & $0.99 * *$ & $0.99 * *$ & $0.96^{* *}$ & 1 & & \\
\hline Drupe Germination & $0.94 *$ & $0.90 *$ & $0.98 * *$ & $0.97 * *$ & $0.97 * *$ & $0.97 * *$ & $0.98 * *$ & 1 & \\
\hline Seed Germination & $0.97 * *$ & $0.94 *$ & $0.99 * *$ & $0.97 * *$ & $0.98 * *$ & $0.98^{* *}$ & $0.98 * *$ & $0.98 * *$ & 1 \\
\hline
\end{tabular}

Note: * Significant at $\mathrm{P}<0.05$; $* *$ Significant at $\mathrm{P}<0.01 ;{ }^{\text {NS }}$ is Non-significant

Fig.1 Geographic locations of the diff erent provenances of $T$. grandis represented in the research study

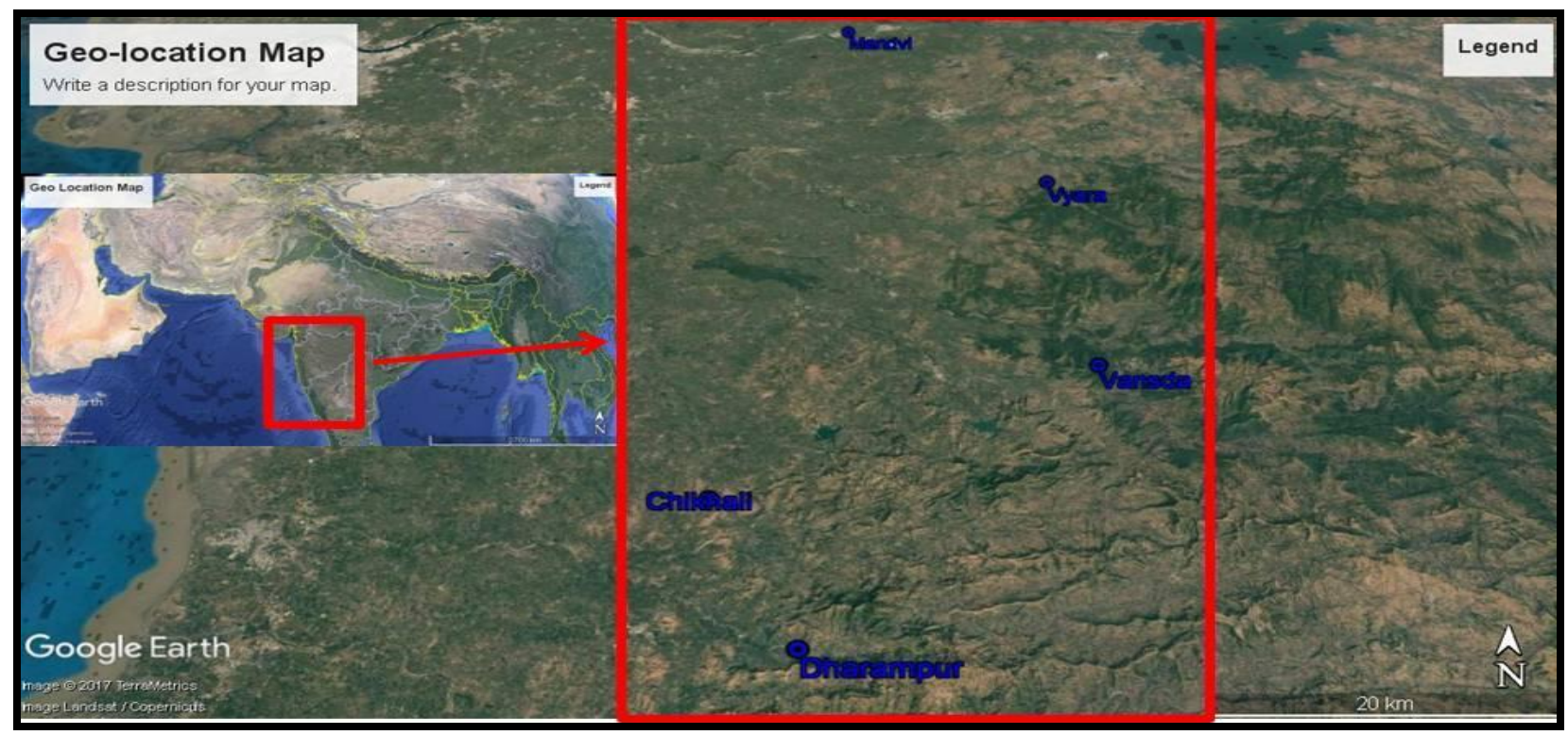




\section{Association between characters}

All the drupe, seed and germination traits showed a strong significant $(\mathrm{p}<0.01)$ positive correlation with each other except drupe width with 100 seed weight (Table 5). Drupe length showed a strong correlation with drupe width $(r=0.98)$ and all others. Then drupe width exhibited a strong correction with seed width $(r=0.96)$ and all others except 100 seed weight. 100 drupe mass showed very strong association with all the traits. Similarly all seed and germination traits were closely associated to each others (Table 5). Sivakumar et al., (2002) was studied intercharacter among drupe and seed traits. They found that drupe diameter, drupe weight, seed weight, filling percent and germination parameters were strongly intercorrelated to each other. Seed width was positively correlated with seed weight in Millettia ferruinea (Loha et al., 2008). Seed length, width and weight of Cordia africana seed were showed strongly positive correlation to each other (Loha et al., 2009). Thus, all the drupe, seed and germination traits closely related to each other and drupe/seed traits influenced on drupe and seed germination according to their bigger size.

The most valuable timber of the world known as king of timber was distributed throughout India, where Gujarat state has natural teak forests. Five teak provenances were studied for drupe, seed and germination traits. All the characters were showed significant differences among five provenances of $T$. grandis. Overall, Mandvi and Dharampur provenances were performed better than all others. Physical dormancy is the major factor for poor germination in teak for deployment of superior genetic materials. Heritability was revealed that selection can be made for seed germination as further genetic improvement of teak while genetic gain coupled with 100 drupe weight. Strong inter-character correlation was found among all the traits and drupe as well as seed traits were influenced on the drupe and seed germination.

\section{Acknowledgement}

Author (RKD) wish to thank department of FBTI and acknowledged the Principal and Dean, College of Forestry, NAU, Navsari, Gujarat for providing necessary facilities during the research study.

\section{References}

Falconer, D.S., Mackay, T.F. 1996. Introduction to Quantitative Genetics. Harlow, UK: Longman Group Ltd., UK. Grime, J.P., Hodgson, J.G., Hunt, R. 1988. Comparative Plant Ecology: A Functional Approach to Common British Species, London.

Gujarat Forest Statistics. 2012. Gujarat Forest Statistics 2010-11. Gujarat Forest Department, Gandhinagar, $105 \mathrm{p}$.

Hedegart, T., Eigaard, J. 1965. Chromosome number of Teak (Tectona grandis L. f.). The Arboretum, Hørsholm, Denmark. Res. Rep., 115.

Hodge, G.R., Dvorak, W.S. 2004. The CAMCORE international provenance/ progeny trials of Gmelina arborea: genetic parameters and potential gain. New Forests, 28: 147-166.

Ibrahim, A.M., Fagg, C.W., Harris, S.A. 1997. Seed and seedling variation amongst provenances in Faidherbia albida. For. Fcol. Manage., 97(2): 197205.

Jayasankar, S., Babu, L.C., Sudhakara, K., Dhanesh, K.P. 1999. Evaluation of provenances for seedling attributes in teak (Tectona grandis Linn. F.). Silvae Genetica, 48(3-4): 115-122.

Johnson, H.W., Robinson, H., Comstock, R. 1955. Estimates of genetic and environmental variability in soybeans. 
Agron. J., 47(7):314-318.

Kaosa-ard, A. 1981. Teak (Tectona grandis Linn. f) its natural distribution and related factors. Nat. His. Bulletin Siam. Soc., 29: 55-74.

Ky-Dembele, C., Tigabu, M., Bayala, J., Odén, P.C. 2014. Inter- and intraprovenances variations in seed size and seedling characteristics of Khaya senegalensis A. Juss in Burkina Faso. Agrofor. Syst., 88(2): 311-320.

Lauridsen, E.B. 2004. Features of some provenances in an international provenance experiment of Gmelina arborea. New Forests, 28: 127-145.

Loha, A., Tigabu, M., Fries, A. 2009. Genetic variation among and within populations of Cordia africana in seed size and germination responses to constant temperatures. Euphytica, 165(1):189196.

Loha, A., Tigabu, M., Teketay, D. 2008. Variability in seed- and seedling-related traits of Millettia ferruginea, a potential agroforestry species. New Forests, 36(1):67-78.

Loha, A., Tigabu, M., Teketay, D., Lundkvist, K., Fries, A. 2006. Provenance variation in seed morphometric traits, germination, and seedling growth of Cordia africana Lam. New Forests, 32(1):71-86.

National Research Center for Agro Forestry. 2007. NARCAF Perspective PlanVision 2025, National Research Center for Agroforestry, Jhansi. $46 \mathrm{p}$.

Pandey, D., Brown, C. 2000. Teak: a global overview. Unasylva, 201 (51): 22-28.

Panse, V.G., Sukhatme, P.V. 1978. Statistical Methods for Agricultural Workers. ICAR, New Delhi. 610p.

Rawat, K., Bakshi, M. 2011. Provenance variation in cone, seed and seedling characteristics in natural populations of Pinus wallichiana AB Jacks (Blue Pine) in India. Ann. For. Res., 54(1): 39-55.

Sivakumar, V., Parthiban, K., Singh, B.G., Gnanambal, V., Anandalakshmi, R., Geetha, S. 2002. Variability in drupe characters and their relationship on seed germination in Teak (Tectona grandis L. f.). Silvae Genetica, 51(5-6):232-236.

Slator, N.J., Callister, A.N., Nichols, J.D. 2013. Mechanical but not physical dormancy is a cause of poor germination in teak (Tectona grandis Lf). New Forests, 44(1): 39-49.

Sojan, J., Indira, E.P. 2010. Variability of seed related characters in teak (Tectona grandis L.f.) from Western Ghat region. Gregor Mendel Fou. J., 1: 39-44.

Tewari, D.N. 1992. A monograph on teak (Tectona grandis Linn. f.). International book distributors, Dehra Dun.

Thompson, K. 1987. Seeds and seed banks. New Phytologist, 106(s1): 23-34.

Venable, D.L., Brown, J.S. 1988. The selective interactions of dispersal, dormancy, and seed size as adaptations for reducing risk in variable environments. American Naturalist, 131(3): 360-384.

Zobel, B., Talbert, J. 1984. Applied forest tree improvement. John Wiley and Sons.

\section{How to cite this article:}

Ravindra Kumar Dhaka and Suman Kumar Jha. 2017. Evaluation of Provenances for Drupe, Seed and Germination Traits in Teak (Tectona grandis L. F.). Int.J.Curr.Microbiol.App.Sci. 6(11): 1721-1727. doi: https://doi.org/10.20546/ijcmas.2017.611.208 